\title{
ニット製品の ぬめり風合い計測法
}

\author{
日本エクスラン工業 西大寺工場＼cjkstart荒 井 康 二 郎 (会員)
}

\section{A Test Method of "Numeri” of Knitted Fabrics.}

\section{Kojiro Arai,}

\section{Saidaiji Plant, Japan Exlan Industry Co., Ltd., Okayama, Okayama-ken.}

\begin{abstract}
Attempts have been done to make clear the physical frictional meaning of smooth slicky feeling so called "Numeri" between wool fabrics and to evaluate the "Numeri" feeling of knitted fabrics as mechanical characteristics, which had been judged with a sensory panel test by human hand.

Analizing the fingers' action of handling at "Numeri" sensory test, it is realized that "Numeri" of knitted fabrics depends on the dynamic frictional behavior between fabrics under finger pressure of 300 up to $1300 \mathrm{~g}$.

This frictional "Numeri" characteristics can be duplicated in figure by means of enlarged measurement of stic-slip friction-slip distances curve by a specially designed heavy loading frictional tester between knitted fabrics. Moreover, the rate of frictional depression at slipping (NI) of an enlarged curve shows good agreement with "Numeri" marks of sensory test.

The heavier the loading, the more distinguishable th difference of this frictional character among test samples as same as high fingers' pressure is found to judge the slight difference of "Numeri" by hand.

(Received January 22, 1973)

摘

要

目 的 従来, 人間の手による官能試験でしか評価できなかったニット製品の「ぬめり」感を力学特性によって 計测, 評価する一方法を提案する。

成 果 (1) ニット製品の「ぬめり」官能判定動作の解析から,「ぬめり」感が, 主として布間の動摩擦特性に 起因することを明らかにした。

(2) ニット製品の「ぬめり」風合い官能判定時の压縮荷重は, 従来の布間摩擦測定条件に比べて高く, 300〜 $1300 \mathrm{~g}$ てあった。

（3）上記結果に基づき，官能判定時の指压を想定した高圧縮荷重下において，布間摩擦の凹凸性を拡大計測する 測定法を開発し, 摩擦力〜変位曲線の形状が,「如風合いの特徴を良く表わしているととを示した. 更に,

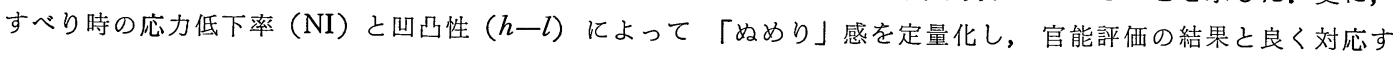
るととを明ら玑しした。

（4）医縮荷重の增加は, 試料間の NI, $h-l$ の差を拡大し, 試料のむつ布間摩擦特性（ぬめり）の特徵を一層明 確にする。乙のことは, 経験的に知られているニット製品を強く握るほど, 試料間の「ぬめり」感の差をとらえや すいととと一致する。
\end{abstract}




\section{1. 諸言}

近年, 布の風合いを力学特性によって表現しようとす る研究が, 主として織物について活発に行なわれている が, その中でも, 松尾らの布の風合いを基本風合いに分 解し，個々の基本風合いと対応する力学特性を計測する ハンドメトリーは実用的ですぐれた方法であり，筆者の 共感するところである。しかし，個々の力学特性の計測 方法は，まだ十分なものではなく，特に布の表面特性， 摩擦特性の評価方法は, 松尾, 小林らによっても指摘さ れているように不十分である.

一方, 綫維の摩擦特性は, 織維工業に扔いて, 加工性 や製品性能上きわめて重要であり, 多くの研究が報告さ れており,すぐれた著書むある。しかし，それらの研究 のほとんどが単繊維静摩擦の理論的, 基碟的研究や, 繊 維加工プロセスに関連した動的摩擦に関するものであ り, 織維製品の性能, 特に風合いに関連した布の摩擦に 関する研究は, 沢路ら゙の絹鳴りの研究, 川端 ${ }^{8)}$ の 織物 （服地）の風合研究などすぐれたあのがあるが，数少な い. 特にニット製品の「ぬめり」感を力学特性と関連づ けた研究はほとんどない.

「ぬめり」感はニット製品, 特にウールのセーターな どの分野で製品の価值を左右する重要な性能であり，布 の摩擦特性との関連が大きい特性であることが経験的に 知られているが，しかし布間の摩擦係数や，布間すべり 時の凹凸性の単なる大小のみでは「ぬめり」感を十分説 明できていないのが実情である.

本報では, ニット製品の「ぬめり」官能判定動作の解 析と, そのシュミレーションから得た, 高压縮荷重下の 布間摩擦測定法によって,「ぬめり」感を機器計測する 方法を見出したのでその検討結果を報告する.

\section{2. ぬめり風合い官能判定動作の解析}

\section{1 触感の分析}

布の風合いを人間の手によって判定する場合，その触 り方にはいろいろな方法があり，たとえば，紳士服地に ついては川端らの報告がある。セータ一などバルキーな ニット製品およびその編地に対しては，よく第1(a)図に 示す触り方が行なわ的る。すすなわち, 人差指, 中指之親

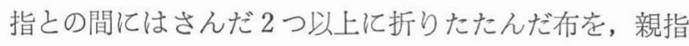
で押しすべらせながら判定する．この時，人間の感覚が 知覚しているのは (1)指之布の接触感, (2)指之布のすへ り抵抗感，(3)布之布のすべり抵抗感，(4)布の厈縮抵抗

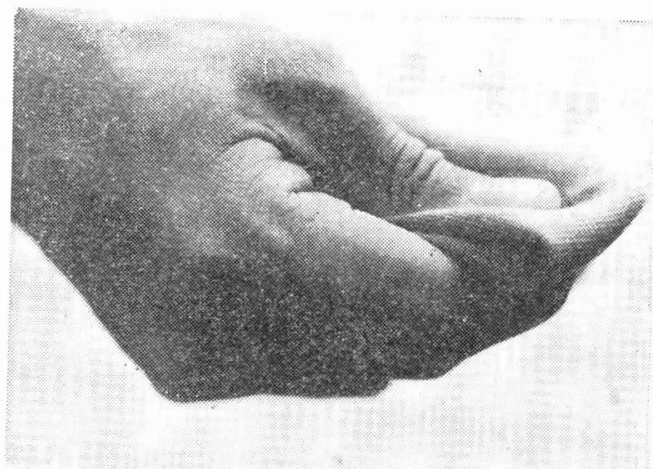

(a) 素手で握る

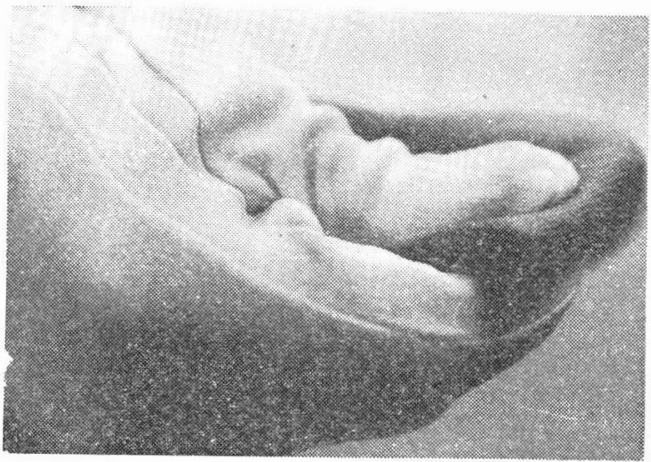

（b）樹脂引手袋をして握る

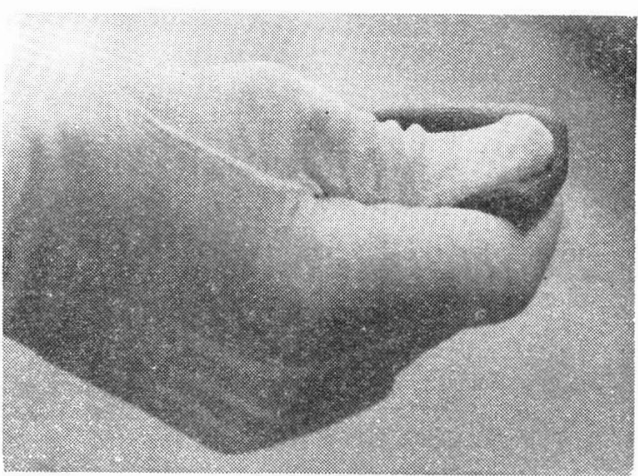

(c) モメン手袋をして握る

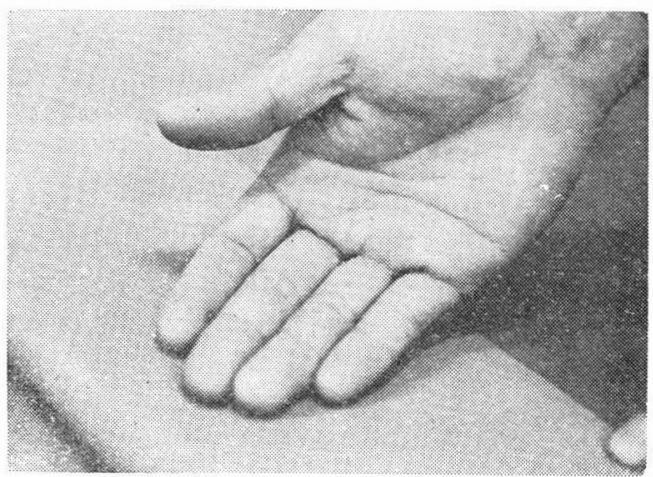

（d）指の甲で布の表面をなでる

（第 1 図）実験 1 亿おける布の触り方 
感と考えられる. 伸長変形, 剪断変形, 曲げ変形あ起と っているであろうが，影響が小さいと考元無視する．布 の圧縮抵抗感は別個に計測可能であり，「ぬめり」感に

（第 1 表）いろいろな触り方をした時の「ぬぬり」 の順位

\begin{tabular}{|c|c|c|c|c|c|c|}
\hline 試 料 & 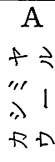 & $\begin{array}{l}B \\
2 \\
1 \\
A\end{array}$ & $\begin{array}{l}C \\
2 \geqslant \\
1 \\
A R\end{array}$ & $\begin{array}{l}\mathrm{D} \\
\overrightarrow{2} \\
\hat{\mathrm{h}}\end{array}$ & $\begin{array}{l}E \\
2 \\
1 \\
\Rightarrow\end{array}$ & $\begin{array}{l}F \\
\vec{D} \\
\vec{B}\end{array}$ \\
\hline (a)素手で握る & 1 & 2 & 3 & 4 & 5 & 6 \\
\hline $\begin{array}{c}\text { (b)樹脂引手袋 } \\
\text { をして握る }\end{array}$ & 1 & 2 & 3 & 4 & 5 & 6 \\
\hline $\begin{array}{c}\text { (c)木綿手袋を } \\
\text { して握る }\end{array}$ & 1 & 2 & 4 & 6 & 3 & 5 \\
\hline $\begin{array}{l}\text { (d)指の甲苼布 } \\
\text { の表面をな } \\
\text { でる }\end{array}$ & 1 & 5 & 4 & 6 & 2 & 3 \\
\hline
\end{tabular}

対して彰響はするが支配的でないととがわかっているの で除外し, 上記 (1)〜(3) の効果を分離し，「ぬめり」感 に対して，そのどれが最む支配的であるかを実験 1 によ って調べた。

\section{〔実験 1】}

ニット製品の風合い判定に経験豊富な専門家に 対し て，第 1 表に示した天筑組織のニット 6 点を示し，第 1 (a) (d)図に示した 4 つの方法で触わらせ, 各方法につい て「ぬめり」感を一対比較順位法で判定してもらった。 視感の影響をなくすため，被験者には目かくしをした。

(a) 素手で, 通常の方法によって握った場合 (標準).

(b) 樹脂引手袋をして(a)之同様に握った場 合（この 時. 布と手袋との間のすべりはほとんどなく，指 之布の接触感むない).

(c) 綿手袋をして (a) と同様に握った場合（との時, 布と手袋との間のすべりは起とるが，指と布の接 触感はない).

（d）素手の指の甲で，布の表面をなぜた場合（指と布 の接触感のみがある).

実験結果を第 1 表に示す. (b) の結果は (a) の結果とま ったく一致し，(c)，(d)は「ぬめり」感の大きく異なる試 料間の差は判定できるが, 比較的小さい差の判定は困難 であった。との結果から，「ぬめり」感は，主として布 間の摩擦特性に起因するむのと考えられる。

\section{2 モデル布間摩擦感覚と「ぬめり」感覚}

「ぬめり」の官能感覚を布間摩擦でモデル的に計測す る場合，その接触条件，圧縮条件を単純化することが必 須であるが，計測結果が良好に官能值と対応するすので

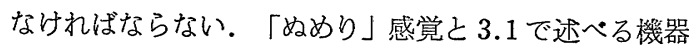
計測法を想定した布間摩擦感覚との対応を実騟 2 にっ て調べた。

[実験 2]

つぎの 4 つの方法による「ぬめり」感覚を (a) 〜 (b), (a) 〜 (c), (a)〜(d)の各組合わせで判定し，その感覚の同一 性を検討した。パネルおよび用いた試料は実験 1 と同じ である。

(a) 通常の方法で握った場合（第 1 (a)図）。

(b) 木製実験台上に 2 枚の試験布を互いに表が接する ように置き，上の布を親指で押しすべらせた場合。

(c) 木製実験台上に なめした鹿皮を置き，その上に 2 枚の試験布を(b) と同様に置いて親指で上の布を押 しすべらした場合.

(d) 下側の布を (c)と同様汇置き，上側試験布を有効 接触面積 $3 \mathrm{~cm}^{2}$ のスライダーに固定して置いて, スライダーを親指で押しすべらせた場合.

(b)よりも (c)の方が，さらに(d)の方が (a)の方法との対 応が良好であった。(b)の場合は，布の組織に基づく凹凸 接触感が拡大して知覚される。(c)は (b)よりも鹿皮の圧 縮性がその凹凸感を吸収し，比較的（a)に近い感覚とし て知覚される。(d)は布と指との直接の接触はなく，指は 布の凹凸性を直接知覚するととなく，布間すべりの凹凸 のみを感じる，(a)の場合，指〜布間のすべりはあまり大 きくなく，主として布間の凹凸性が指に知覚されている あのと推定される。したがって, 試料台と試験布の す ベりは，布間のすべりより小さいてとが必要であり，鹿 皮はての役目を果たしていると考えられる．計測時の試 験布間の接触条件については，まだ工夫の余地がある.

\section{3 官能判定時の圧縮荷重}

従来の布間摩擦測定の圧縮荷重は比較的小さく，た之 えば松尾らは $50 \mathrm{~g} / 2 \mathrm{~cm}^{2}$ の条件を採用している。 、バル キーニット製品の「ぬめり」感を評価する専門家の判 定動作と, そのときの布変形の観察, および筆者の布を 握った時の圧縮感覚から，布間に作用する圧縮荷重は数 $100 \mathrm{~g}$ のオーダーであるととが予想された。また試料間 の「ぬめり」感の差が小さいときは, 強く握るとその差 をとらえやすいことが経験的に知られている，乙れらの ことから, 官能判定時の圧縮荷重を知るととが「ぬめ り」計測化の条件設定のために重要と考え実験 3 亿よっ て圧縮荷重を実測した。

[実験 3 ]

ニット製品の風合い判定に経験豊富な専門家に対して 
実験 1 の試料および各種の油剂処理をほどてした天竺組 織のアクリル ニット数点を示し, 共和電業(侏)製超小型 圧力変換器 P S - $2 \mathrm{KA}$ 型を, 第 1 (a)図の布の間にはさ んで, 通常の方法で「ぬめり」判定動作を行ない, P S - 2 K A で検出した圧縮力を記録計に記録した。

この結果，たとえばカシミヤ肌着や細デニル使いのウ ールセーターのように,「ぬめり」感の良好な布に対し ては300〜500 g，たとえば柔軟剤のわずかに異なるアク リルセーター間のように，比較的小さい「ぬぬり」感 の差を判定するときには，700１300 gという. 従来の 布間摩擦測定条件に対して，大きな圧縮荷重の作用して いるととが明らかとなった．官能判定時の加圧荷重は, 対象とする「むの」（たとえば織物, ニットなど）によ って異なるであろう. たとえば, 紳士服地についての専 門家が, 婦人セーターの風合いを判定すると必ずしあ良 い判定結果が得られるとは限らない, と言われる原因 は, 注目する変形挙動の違いと同時に, 加圧荷重の差に あ一因があるあのと推定される.

また, 判定動作の観察から, 指で圧縮される布間の接 触面積は約 $3 \mathrm{~cm}^{2}$ 之推定された。

\section{3. 布間摩擦による「ぬめり」計測}

\section{1 測定法}

測定装置の概要を第 2 図に示した。乙の装置による布 間摩擦特性計測図を第 3 図に示した。一端を固定し, 他 端に $30 \mathrm{~g}$ の荷重を作用させた試験布を固定した試験台 を, $12 \mathrm{~mm} / \mathrm{min}$ の等速で移動させ，スライダーに固定 した試験布との間に発生する摩擦抵抗力を, スライダー に接続した抵抗線歪計で検出し, 増幅, 記録する.てれ を第 3 図で説明すると, 試料台の移動に伴い，まず布間 のすべりが起こらずに応力の増加がみられ $(\mathrm{A} \rightarrow \mathrm{B})$,

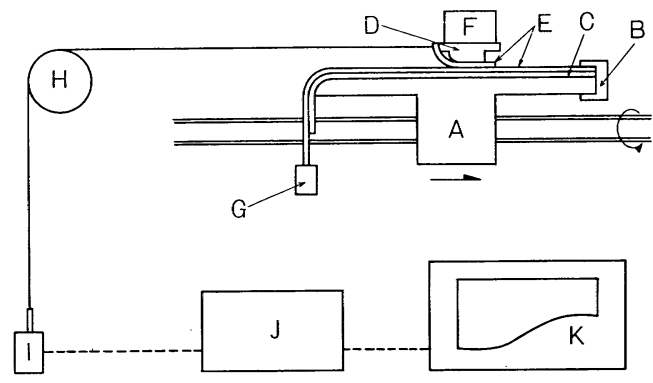

$\mathrm{A}$ : 試料台, B : 試料押さえ, C : 鹿皮, $\mathrm{D}:$ : スイダー, E : 試料, F, G : 荷重 $\mathrm{H}$ : 滑車, I : ストレインゲージ, J : 増幅器 $\mathrm{K}$ : 記録計

（第 2 図）布間摩擦測定装置
最大值 (C)を経て動摩擦力のレベルでほぽ一定となる。 (B)乙こでゼロ点を低応力側にシフト $(\mathrm{D} \rightarrow \mathrm{E})$ した後, 感度を 5 〜 10倍にアップ $(F \rightarrow G) し ，$ 動すべりの凹凸を 拡大計測する. 第 3 図の (b)は (a)の H部分を拡大図示し たものである。この計測図から次の 5 特性を定義した。

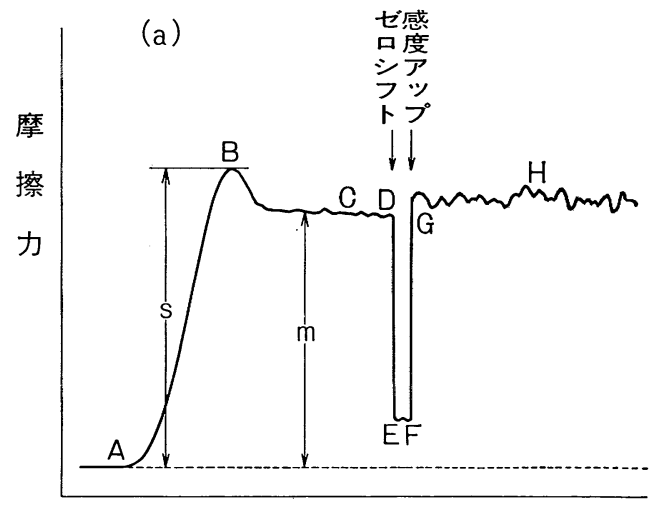

変 位

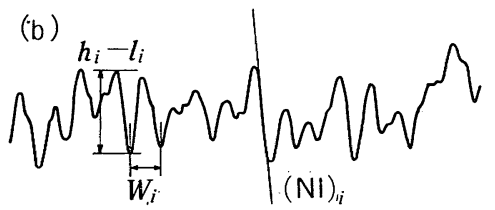

（第3図）布間摩擦計測説明図 (b)は(b)のH部分の拡大図である

\section{（記号）（単位）（定義）}

$\begin{array}{llll}\text { 静摩擦力 } & S & \mathrm{~g} \\ \text { 動摩擦力 } & m & \mathrm{~g} \\ \text { すべり凹凸性 } & h-l & \mathrm{~g} & \frac{1}{n} \sum_{1}^{n}\left(h_{i}-l_{i}\right) \\ \text { 凹凸のピッチ } & w & \mathrm{~mm} \frac{1}{n} \sum_{1}^{n} w i \\ \text { すべり匂配 } & \mathrm{NI} & \mathrm{g} / \mathrm{mm} \frac{1}{n} \sum_{1}^{n}(\mathrm{NI})_{i}\end{array}$

この中で特に布間のすべりやすさとしての $m$ ，凹凸 感としての $h-l$, 狭義の「ぬめり」感としての NI が注 目するべき特性值と考えられる．NI は「ぬめり」感が， 「布間の動的すべり時の応力変化である」と仮定する 之, 等速変形時の応力増加率（凹凸の立上がり）は一定 であり(このとき布間のすべりは起こっていない), 人 間の指がすべりを感じるのは応力低下の起てるとき（布 間のすべりが起てっている）であり，試料布の「ぬめ り」の特徵が, 応力低下率で明確化されると予想された ことに基づいて定義された. NI は第 3 図 (b)に打いて摩 擦力が低下するときの直線部分の勾配であり, 試料台と スライダーの相対移動距離 $1 \mathrm{~mm}$ 当たりの低下応力( $(\mathrm{g})$ で 
表示した。

ての計測系の ばね定数は $190 \mathrm{~g} / \mathrm{cm}$ であり，ばね定 数に対して摩擦力が大きいととから，また計測時に試料 台の移動を停止させると，あはやスティックースリップ 波形を示さない実験事実から，乙の系の減衰は大きく固 有振動の影響は無視できる。

3.2 布間摩擦特性の圧縮荷重依存性之 「ぬめり」感覚の対応

\section{〔実験 4]}

ぬめり感の異なる天竺組織ウールニット 2 点（第 2 表の試料No. 2 および No. 8）を用い，3.1で述べた測 定法により (1)移動速度 $12 \mathrm{~mm} / \mathrm{min}$ ，(2)スライダーの有 効接触面積 $3 \mathrm{~cm}^{2}$ ，(3)圧縮荷重 $10 \mathrm{~g}, 50 \mathrm{~g}, 143 \mathrm{~g}, 450$ $\mathrm{g}$ 亿术ける布間摩擦挙動を計測し, 各特性値の圧縮荷重 依存性を検討した。

実験結果を第 $4 \sim 6$ 図に示す.「ぬめり」感に明膫な 差のある試料です， $m$ は圧縮荷重 10４50 g の範囲で差 はない (第 4 図). $h-l$ および NI は, 圧縮荷重の増加 に伴って試料間の差が拡大し（ぬめり感の大きいほど $h$ $-l, \mathrm{NI}$ とあ小さい.) 圧縮荷重 $100 \mathrm{~g}$ 以上でその増加 率が鈍化する．乙のことは, ニットの「ぬめり」判定時 に高い圧力を作用させるととが妥当であるとと，強く握 るほど「ぬめり」の試料間の差が明瞭になるとと，を良 く説明している，凹凸のピッチ（w）は 2 試料とも，ヤ 一ンの太さに対応する $1 \mathrm{~mm}$ であり, 圧縮荷重の増加に よりやや大きくなるが，乙れは布の伸長変形に起因して いる. $h-l$ の $m$ に対する比率は圧縮荷重の増加に伴っ

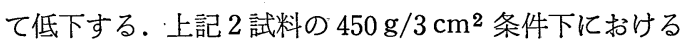

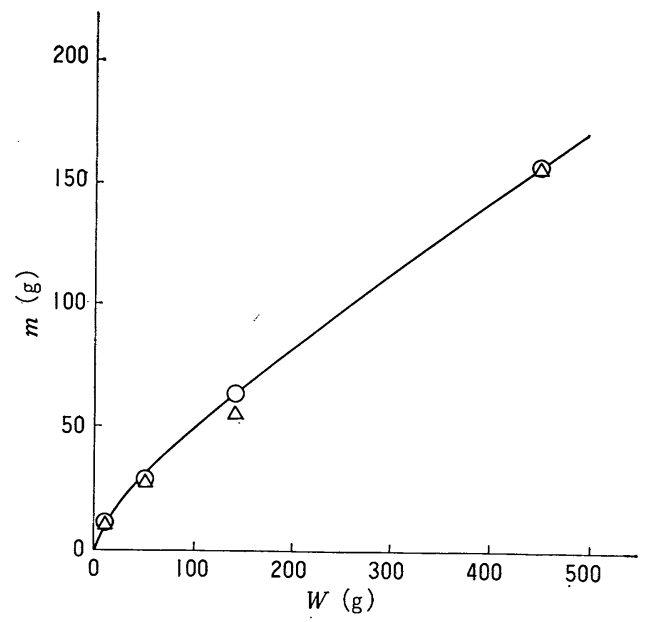

○:試料 No. $2, \triangle$ : 試料 No. 8

（第 4 図）ぬめり感の異なるウールニットの布間 動摩擦荷重依存性 $(h-l) / m$ は $2 \sim 5 \%$ $\%$ あ， $m$ 之同じ計測条件で $h$-lの微少な差をとらえることは困難である。したがっ て高圧縮荷重下の布間摩擦計測においては，感度を増す ことによって凹凸性を拡大して計測するてとが，きわめ て重要であると言える.

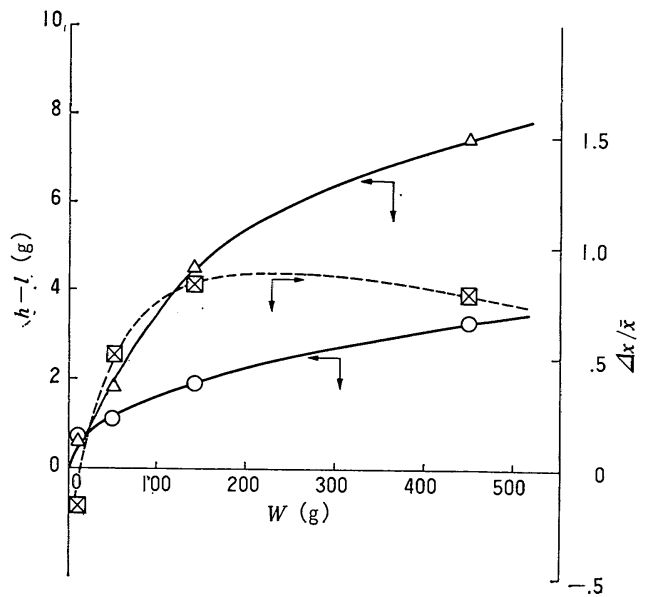

冈は 2 サンプルの $(\mathrm{h}-\mathrm{l})$ の差を平均値で割った值 $\bigcirc$ : 試料 No. 2 (ぬめり大), $\triangle$ : 試料 No. 8

（第 5 図）ぬめり感の異なるウールニットの布間 摩擦凹凸性 $(h-l)$ の圧縮荷重依存性

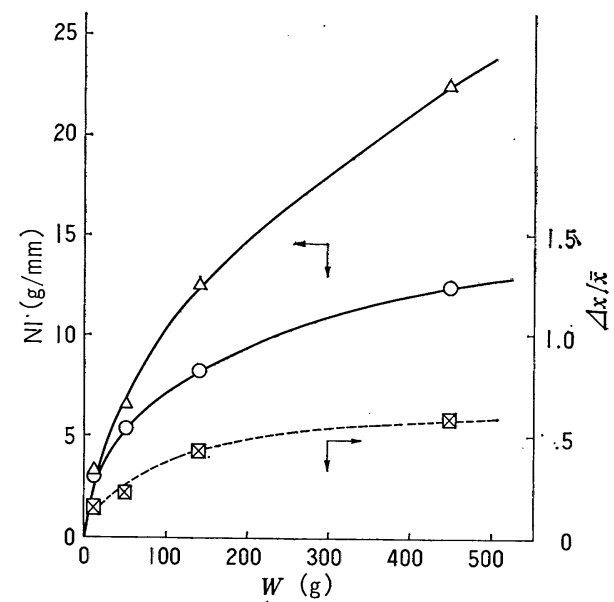

邓は 2 サンプル間の差を平均值で割った值 $\bigcirc$ : 試料 No. 2 (ぬめり大) $\triangle$ : 試料No. 8

（第 6 図）ぬぬり感の異なるウールニットの布間 摩擦 NI の圧縮荷重依存性

3.3 ウール ニットの布間摩擦計測例とその 「ぬめり」感覚との対応

\section{[実験 5]}

第 2 表に示す天竺組織セータ一類 9 点について， 3.1 で述べた測定法により，(1)移動速度 $12 \mathrm{~mm} / \mathrm{min} ，(2)$ ス 
（第 2 表）ぬめり計测試料明細

\begin{tabular}{|c|c|c|c|c|c|}
\hline $\begin{array}{c}\text { 試料 No. } \\
\text { (官能判定ぬめり順位) }\end{array}$ & 試 & 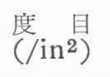 & $\begin{array}{l}\text { 目付け } \\
\left(\mathrm{g} / \mathrm{m}^{2}\right)\end{array}$ & $\left|\begin{array}{c}\text { 番 } \\
(x-ト ル \text { 番手 })\end{array}\right|$ & 備 \\
\hline 1 & 紳士肌着（カシミヤノウール） & 284 & 273 & $2 / 21$ & 市販品 \\
\hline 2 & 紳士肌着（カシミャ／ウール） & 285 & 263 & $2 / 21$ & 市販品 \\
\hline 3 & 紳士セーター（ウール100\%） & 569 & 257 & $2 / 75$ & 市販品 \\
\hline 4 & 紳士セーター（ウール100\%） & 601 & 375 & $2 / 73$ & 市販品 \\
\hline 5 & 子供セーター（ウール100\%） & 387 & 329 & $2 / 45$ & 市販品 \\
\hline 6 & 紳士セーター（ウール100\%） & 389 & 277 & $2 / 51$ & 市販品 \\
\hline 7 & 紳士セーター（ウール／アクリル） & 415 & 242 & $2 / 32$ & 市販品 \\
\hline 8 & 紳士セーター（ウール100\%） & 584 & 256 & $2 / 78$ & 市販品・防縮加工 \\
\hline 9 & 試作編地（ノーオイルアクリル） & 409 & 242 & $2 / 36$ & $\mathrm{CCl}_{4}$ で脱脂 \\
\hline
\end{tabular}

（注）いずれむ天竺組䋍

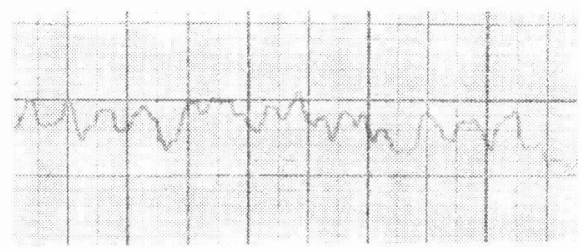

(a) 試料 No. 2, カシミャ/ウール

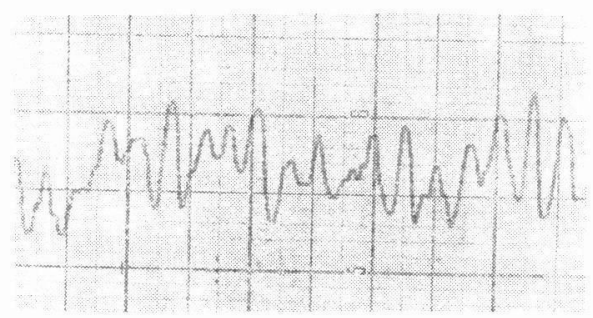

(b) 試料 No. 4, ウール

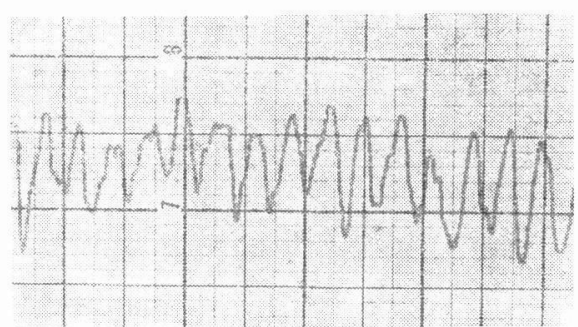

(c) 試料 No. 7, アクウル ウ ウール

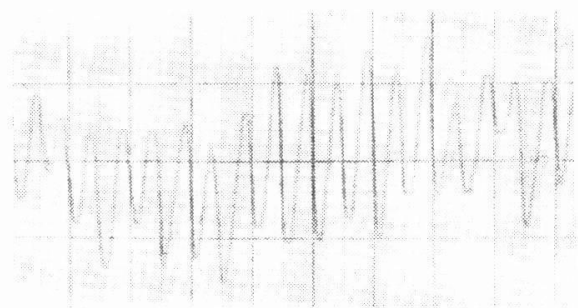

(d). 詰料 No. 8, ウール

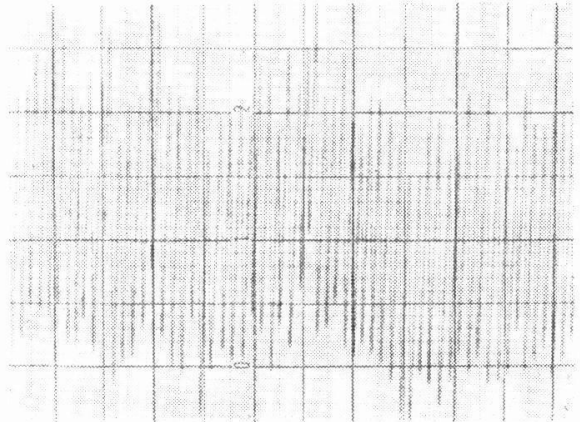

(e) 試料 No. 9 , ノー オイル アクリル

（第 7 図）布間摩擦計测波形の例

（第 3 表）ぬめり感の異なる試料の布間摩擦特性

\begin{tabular}{c|r|r|r|r|c}
\hline \hline $\begin{array}{c}\text { 陚料 No. } \\
\text { 覑位 }\end{array}$ 判定ぬぬり $)$ & $S$ & $m$ & $h-l$ & $w$ & NI \\
\hline 1 & 156 & 108 & 1.47 & 1.47 & 6.8 \\
2 & 187 & 126 & 2.88 & 1.41 & 7.8 \\
3 & 166 & 153 & 3.76 & 1.32 & 13.8 \\
4 & 172 & 152 & 4.26 & 1.09 & 13.6 \\
5 & 201 & 177 & 4.50 & 1.33 & 16.2 \\
6 & 162 & 150 & 5.30 & 1.23 & 17.0 \\
7 & 168 & 149 & 4.79 & 1.18 & 18.3 \\
8 & 187 & 161 & 6.33 & 0.96 & 27.0 \\
9 & 270 & 186 & 15.56 & 0.33 & $>100$ \\
& & & & & \\
\hline
\end{tabular}

ライダーの有効接触面積 $3 \mathrm{~cm}^{2}$, (3)圧縮荷重 $450 \mathrm{~g}$, (4) 記録紙送り速度 $60 \mathrm{~mm} / \mathrm{min}$ での布間摩擦挙動を計測し, その波形および特性值を求めた。「ぬめり」官能判定順 
位は実験 1 (a)の方法で決定した.

計測波形の一例を第 7 図に示した．著しく「ぬめり」 感のあるカシミャニットは凹凹が小さく, 滑らかな波 形を示す.「ぬめり」感の良好なウールニットは滑ら かな波形であり，凹凸は比較的小さいが，カシミヤニッ トに比べると大きい. ウールニットでも防縮加工した 試料 No. 8 の波形は滑らかではあるが凹凸が大きく, 試

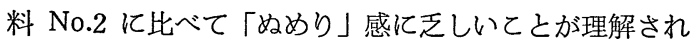
る.また合成繊維の中で最もウールに近い風合いをすつ といわれるアクリル繊維とウールとの混紡品は, 比較的 「ぬめり」感の良好なウールニットに近い布間摩擦波 形を示している.アクリル繊維は, 通常その「ぬめり」 感をよりウールに近似させるために, 各種の柔軟処理剂 を付着させており, その布間摩擦波形はウールに近似し ているが, モデル的に四塩化炭素で柔軟剤をまったく取 り去った試料 No. 9 は鋸歯状の典型的なスティックース リップ波形を示し, ぎしぎしした触感を示すととが波形 から良く理解できる。

このように. 布間摩擦波形によって布の「ぬめり」感 を表現するととができるが, 数值化することによって応 用範囲が一層拡大する. 第 3 表に測定結果を示すが,

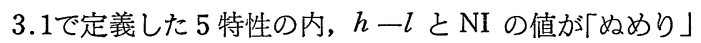
感の官能判定結果と良く一致している. $h-l$ とI の 2 軸直座交標上に各試料の計測值をプロットし, 第 8 図に



図中の添字は「ぬめり」感官能判定の順位を示す 試料 No.9 は図の古く内をはずれ右上方に位置 する

(第 8 図) ぬめり感の異なる布間摩擦 $(h-l)$ と NI
示した. 添記した数字は, 第 2 表の試料 No. であり, 「ぬめり」官能評洒の順位である．典型的なスティック 一スリップ波形を示す試料 No.9 はこのグラフのわく をはずは，はるか右上方に位置する。乙れらの結果か ら，h-l, NI がとあに小さいときは, カシミヤ, ウー ルライクな「ぬめり」となるととがわかる. $h$ 一l が大 で NI が小のときは凹凸感のある「ぬめり」，h-l が 小で NI が大のときは, 凹凹感はないが「ぬめり」のそ しい風合いを示すすのと推定される。

\section{4. 結言}

本報ではニットの「ぬめり」風合いの官能判定動作を 解析し,「ぬめり」感が主として布間の摩擦特性, 特に すべり時の応力変化に依存するととを明らかにし，布間 すべり時の凹凸性を拡大して計測する方法, および官能 評価との一致性について述べた，本計測法は，波形のデ ィジタル化にまだ改善の余地を残しているが，従来官能

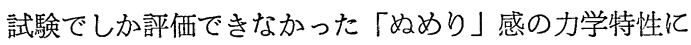
よる評価を可能にした。

本計測法の特長は, 従来の布間摩擦測定法に比べ, (1) 人間の指圧を想定して高圧縮荷重を作用させたとと，(2) すべり時の凹凹性を測定感度を上げるととにより拡大し て計測したこと（3)すべり勾配（NI）など力学特性值に よって「ぬめり」感を数值化したてとにある。

本測定法による計測例はまだ少なく，織物，組織の異 なるニット製品などに範囲を拡大し，その有用性の確認 が必要である.

最後に, 本研究の発表を許可された日本エクスラン工 業(侏)西大寺工場, 中島章研究部長, 本研究に際しご指導 いただいた関口英人室長, 曽根正夫主任研究員, ならび に本研究に協力いただいた野村勝昭, 竹原晴雄両氏に感 謝の意を表する.

\section{文献}

1）たとえば, 日本繊維機械学会. 織物の風合い講習テ キスト(1971) 繊維学会関西支部. 第 6 回緎維科学 講座テキスト(1971)

2）松尾；繊機誌，23，T134（1970）

3）那須, 斎藤, 松尾; 繊機誌, 24, T58 (1971)

4）原田，斎藤，松尾；緎機誌，24, T126 (1971)

5）小林; 繊維と工業, 3, 753 (1970)

6) H.G. Howell K.W. Mieszkis, D. Tabor; Friction in textile, Butterworths Scientific Publication, 1959

7）沢路, 川口, 乾; 繊維機械学会要旨集 C-22(1970)

8）たとえば川端；䋐維と工業，5，277（1972）

9) 川端; 瀻維機械学会第 24 回年次大会講演論文集 p.15 4 (1971) 